АЛЕРГИЈСКИ РИНИТИС И БРОНХИЈАЛНА АСТМА У

616.248-084 ОРДИНАЦИЈИ ИЗАБРАНОГ ЛЕКАРА - приказ сЛУчаја

Анита Накићํ, Весна Динов ${ }^{2}$, Наташа Михајловић ${ }^{3}$

\title{
ALLERGIC RHINITIS AND BRONCHIAL ASTHMA AT THE OFFICE OF SELECTED PHYSICIAN - case report
}

Anita Nakić, Vesna Dinov, Nataša Mihajlović

\section{Сажсетак}

Алергијски ринитис и бронхијална астма су врло често удружене болести. Многе епидемиолошке, патофизиолошке и клиничке студије потврђују повезаност ринитиса и астме. Проценује се да око 40\% оболелих од алергијског ринитиса има астму, док око 80\% астматичара има алергијски ринитис. У око 20\% болесника јавља се истовремени развој болести.

Приказана пацијенткиња јавља се у ординацију изабраног лекара после више месечи присутних тегоба учесталог кијаюа, углавном ујутру. После кијања не долази до олакшања. Повремено се јавља и кашаљ, свирање угрудима, чешће ноћу кад се умири. У пар наврата имала је и нападе гушења. Континуирана изложеност факторима ризика, без предузимања мера превениије и лечена резултирали су појавом удружених болести. Уз успостављање партнерског односа и дисциплине пацијента, долази до стабилизације болести те пацијенткиња није имала потребу за хоспитализачијом. Ефикасна контрола астме захтева проактивни и превентивни приступ болести, слично контроли оболелих од дијабетеса и повишеног крвног притиска.

Циљ рада: Указати на значај правовременог јављаға лекару на преглед ради ране идентификачије алергијског ринитиса у ичиљу предузимања превентивних мера и едукачије болесника за контролу астме.

Кључне речи: удружене болести, превентивне мере, едукачија болесника.

\section{Summary}

Allergic rhinitis and bronchial asthma are very often associated diseases. A large number of patients suffering from rhinitis developed asthma during life. Many epidemiological, pathophysiological and clinical studies confirm the connection between rhinitis and asthma. It is estimated that about $40 \%$ of patients with allergic rhinitis have asthma, while around $80 \%$ asthmatics have allergic rhinitis. About $20 \%$ of patients report the simultaneous development of the disease.

Featured patient shows up at the Office of the selected physician after several months of present problems of frequent sneeze, mainly in the morning. After the sneeze there is no relief. Occasionally there is cough, whispering in the chest, more often at night when it's calm. A couple of times she had suffocation attacks. Continuous exposure to risk factors, without taking measures of prevention and treatment may result in the emergence of joint disease. With the establishment of partnership relations, patient discipline, disease stabilization and patient did not have the need for hospitalization. Effective asthma control requires proactive and preventive approach to disease, similar to the control of patients with diabetes and high blood pressure.

The aim of the study: to point out the importance of timely reporting to the doctor for early identification of allergic rhinitis in order to take preventive measures and education of patients to control asthma.

Key words: associated diseases, preventive measures, education of patiens.

\footnotetext{
${ }^{1}$ Др Анита Накић, лекар на специјализацији опште медицине, Здравствени центар, Врање, Служба опште медицине, Дз Врање, Ј.J. Лунге 1.

2 Др Весна Динов, лекар на специјализацији опште медицине, Здравствени центар, Врање, Дз Врање, Служба опште медицине, Ј.Ј. Лунге 1.

${ }^{3}$ Др Наташа Михајловић, лекар на специјализацији опште медицине, Здравствени центар Зајечар, Служба кућне неге, Расадничка бб.
} 


\section{УВОД}

$\mathrm{A}$ лергијски ринитис је најчешћа хронична респираторна болест која је у коморбидитету са астмом и за коју је уједно и највећи фактор ризика. ${ }^{(1)}$ Испољава се кијањем, запушеношћу носа, ринорејом, а изазвана је инхалационим алергенима. ${ }^{(2,3)}$ Према дужини експозиције узрочном алергену алергијски ринитис је подељен на сезонски (изазван алергенима спољашње средине) и перенијални (изазван алергенима затвореног простора). Према дужини трајања симптома подељен је на интермитентни и перзистентни, према тежини: благи, умерени до тешки и према експозицији узрочном алергену на сезонски, перенијални и професионални. Астма је хронична инфламаторна болест дисајних путева и удружена са бронхијалном хиперреактивношћу доводи до рекурентних епизода визинга, гушења, стезања у грудима и кашља, посебно ноћу и рано ујутру. Већина пацијената са астмом су атопичари (екстризик астма), мањи број припада групи не атопичара (интризик астма). Фамилијарна предиспозиција, атопија и излагање алергенима и сензибилишућим агенсима значајни су фактори ризика за алергијски ринитис и астму. ${ }^{(4-6)}$ Алергијски ринитис и бронхијална астма су хроничне и врло често удружене болести. Захваљујући едукацији болесника, превенцији и савременом развоју лекова пацијент може да има добар квалитет живота. ${ }^{(1,7,8)}$

Неопходно је изналажење најоптималнијег лечења пацијента са алергијским ринитисом, са циљем да се спречи или успори развој бронхијалне астме.(8) Нелечени алергијски ринитис доводи до слабије контроле астме, док се адекватним лечењем алергијског ринитиса побољшава контрола болести, смањује потреба за хитним интервенцијама и употреба симптоматске терапије.

Превенција астме темељи се на принципима превенције алергијског ринитиса, односно избегавању контакта са алергеном, као и правовременој примени медикамената који у кратком времену могу довести до побољшања стања. Оптимално лечење алергијског ринитиса, доводи и до истовремене стабилизације астме.

Успостављање партнерског односа и едукација болесника се сматрају кључним у успешној превенцији и лечењу болесника са алергијским ринитисом и астмом. Показало се да без едукације нема задовољавајућег смањења оболевања па и смртности. Важно је болесника упознати са његовом болешћу, могућностима њеног лечења и потребним редовним контролама. Нажалост, у порасту је број пацијената којима треба већи број лекова и њихова свакодневна употреба, јер се не јављају на време лекару, па се и дијагноза не постави на време. Срећом астма се може ефикасно лечити и код већине се може постићи добра контрола болести. ${ }^{(1,7)}$

\section{ПРИКАЗ СЛУЧАЈА}

Пацијенткиња стара 64 године болује од артеријске хипертензије. Јавља се у амбуланту због учесталог кијања „у нападима“ праћених цурењем обилног воденастог секрета; а у последњих десетак дана, чешће ноћу кад се умири, јављају јој се честе епизоде непродуктивног кашља, тескоба и свирање у грудима. У пар наврата је имала и нападе отежаног дисања који су пролазили спонтано, после устајања и излажења на свеж ваздух.

Тегобе повезује са прехладом (кијање, кашаљ, повишена температура, болови у мишићима) коју је имала пре око четири месеца. Наводи да је и у околини било сличних случајева тих дана. Од тада скоро свакоднево кија, помало кашље, има утисак да је често прехлађена. Због планираног пута у САД, није придавала значај симптомима. По одласку у иностранство, после пар дана јавља се и упорна кијавица са цурењем из носа обично у јутарњим сатима, после чега је осећала малаксалост и исцрпљеност. Наводи да је била и у контакту са прашином јер су у кући нешто сређивали. Пријао јој 
је боравак на отвореном, у природи. Иако је имала здравствено осигурање, одлаже одлазак лекару. Користила је мултивитаминске препарате. По повратку у Србију, после три месеца, напади кијања су учестали и јавља се свирање у грудима, кашаљ са оскудним испљувком, као и напади отежаног дисања. Сметају јој нагле промене температуре, нарочито хладно и магловито време, лако се замара, има честе несанице, немирно спава.

Пацијенткиња је непушач, али јој је одувек сметао дим од цигарета, супруг је пушач. Негира алергије у породици. Увидом у здравствени картон пар пута раније имала оралну кандидијазу.

При прегледу афебрилна, еупноична, кожа нормално колорисана. Ендоназално едематозна, влажна, светлоружичаста мукоза обострано, присутна бистра секреција. Аускултаторни налаз над срцем уредан, на пућима ретки високотонски звиждуци обострано, ТА125/80.

Након физичког прегледа, лабораторијских налаза SE 7, RBC 4,46, WBC 7,1, NEU 41,91, EOS 15,1, LYM 37,5, CRP 7, глукоза 4,8 mmol/1 и биограма спутума: Escherichia coli, гљиве рода Candida 15 колонија, ординирана је терапија: антибиотик по антибиограму, антимикотска терапија, антихистаминик и капи за нос на бази морске воде и дат савет о промени начина живота и исхране.

Стање се по примењеној терапији побољшало, али се опет повремено јављало кијање и свирање у грудима. Поновљене су лабораторијске анализе и утвђено присуство еозинофилија (EOS 9,3), у микробиолошком налазу бриса језика Candida 5 колонија и имунолошки налаз са укупним $\operatorname{IgE}$ 390,1. Предложено алергијско тестирање на инхалационе алергене није рађено. Након консултације пулмолога, када су урађене радиографија плућа (налаз уредан) и спирометрија (присутна инсуфицијенција плућне вентилације мешовитог типа лаког степена FVC 65\%, FEV1 $77 \%$, PEF 60\%), потврђена је дијагноза алергијског ринитиса и бронхијалне астме. Препоручена је терапија: антихисаминик (цетиризин $10 \mathrm{mg}$ ) 1 ујутру, модификатор леукотријена (монтелукаст $10 \mathrm{mg}$ ) 1 увече и бета 2 адренергички агонист брзог деловања (салбутамол) уколико осети недостатак ваздуха, свирање у грудима.

На контролном прегледу, после месец дана, стање болеснице било је значајно побољшано, без кијања и кашља, отежаног дисања. Наводи да се рафално кијање, свирање у грудима јавило, јер пар дана није узимала терапију. Тада је узела поред редовне терапије 2 удаха салбутамола. Аускултација плућа је уредна; на контролној спирометрији налаз уредан, без знакова опструкције (FVC 89\%, FEV1 91\%, РEF $74 \%$ ). Указано је на неопходност редовне употребе терапије и важност редовних контрола пулмолога на 3 до 6 месеци, по потреби и раније.

Пацијеткиња је укључена у групну терапију (рад у малој групи), чиме је олакшан индивидуални приступ, а истовремено омогућена едукација већег броја оболелих.

Уз терапију и придржавање мера избегавања алергена, промене и побољшања животних услова астма је била добро контролисана.

\section{ДИСКУСИЈА}

Континуирана изложеност факторима ризика, без предузимања мера превенције и лечења, резултирала је појавом удружених болести. У приказаном случају наведена прехлада, промена животне средине и континуирана изложеност прашини су вероватно били фактори ризика који су утицали на пад имунитета (налаз биограма: Candida у спутуму и на језику) и појаву удружених болести. Поред присутних и погоршавајућих тегоба пацијенткиња је из наведених разлога одлагала одлазак лекару што је резултирало истовременом дијагностиком алергијског ринитиса и бронхијалне астме. И наизглед лакши поремећаји 
здравља (прехлада, ринитис) захтевају сарадњу пацијента и лекара, јер ако се не лече могу бити узрок компликација, лошег квалитета живота и већих трошкова лечења. Потребна је свеобухватност у приступу како би се збринуле обе хроничне болести и здравственом едукацијом болесник оспособио да се носи са новонасталом ситуацијом.

Саветовано је препознавање и избегавање најчешћих алергена (гриње, продукти кућних љубимаца, алергени инсеката) и иританаса из околине, што је у свакодневном животу врло тешко. Потребно је редовно проветравање просторија и боравак у природи, избегавање задимљених простора. Саветовано је да супруг престане да пуши. Вирусне инфекције могу проузроковати или погоршати алергијски ринитис и напад астме. Препоручена је вакцина против грипа. Важна је редовна хигијена и испирање носа (коришћење препарата на бази морске воде). Болесница је приметила да се напади кијања и свирање у грудима јављају припромени температуре, повећаној влажности ваздуха, као и да јој сметају велике температурне разлике. Предложено је да прати биометеоролошку прогнозу, да смањи физичку активност и редовно узима терапију. Потребно је научити пацијента да правилно користи лекове, да схвати разлику између лекова за контролу астме и лекова за олакшање тегоба. Значајно је да препозна знаке погоршања, а за хитна стања мора имати уз себе лек за брзо прекидање напада гушења (салбутамол). ${ }^{(9)}$

За лечење алергијског ринитиса предложен је орални неседативни антихистаминик. Контролни преглед је био уредан, те није било потребе за увођењем назално локалног стероида. ${ }^{(1,2)}$ Према међународним смерницама лекови првог избора у лечењу астме су инхалациони кортикостероиди, јер њихова примена омогућује добру контролу болести и спречава губитак плућне функције. ${ }^{(7-10)}$ Због удружености алергијског ринитиса и бронхијалне астме и већ присутне кандидијазе лек избора је био модификатор леукотријена. У циљу брзог отклањања симптома користе се бета 2 агонисти брзог и кратког деловања, салбутамол по потреби. Уколико се користи више од два пута недељно, потребно је променити основну терапију. ${ }^{(8,9)}$

За дијагнозу и праћење терапијског ефекта астме користи се мерење максималног експиријумског протока (PEF), који се изводи након дубоког инспиријума из тоталног плућног капацитета. Дневни мониторинг је уобичајен за процену тежине астме и њеног одговора на терапију. Он може помоћи пацијенту у детектовању раних симптома астме.

Због проблема мерења контроле астме у свакодневној пракси група QualityMetric Inc. лиценцирала је тест за одређивање контроле астме. Тест за контролу астме (Asthma control test - ACT) је значајан за откривање неконтролисане астме. Тест се састоји из пет питања, што је једноставна метода која може да се понови на сваком контролном прегледу. ${ }^{(11)}$

За постављање дијагнозе, лечење и адекватно праћење болесника са алергијским ринитисом и астмом неопходна је и сарадња изабраног лекара са пулмологом, оториноларингологом и кроз консултације постизање адекватне контроле здравственог стања болесника. Коришћење здравствене заштите, доступност здравствене службе и заступање пацијентових интереса су кључни у постизању жељених ефеката исхода лечења.

\section{ЗАКЉУЧАК}

Циљеви терапије алергијског ринитиса су: контрола симптома болести, побољшање квалитета живота, смањење ризика од компликација. Астма је под контролом када болесници имају мање симптома или су без њих, укључујући и ноћне, ретко користе или не користе лекове за олакшање тегоба, без погоршања болести и без потребе за 
хитном интервенцијом, имају продуктиван, физички активан живот, нормалну или скоро нормалну плућну функцију. ${ }^{(1,7)}$

Уз успостављање партнерског односа и дисциплине пацијента (редовни одласци код лекара) долази до стабилизације болести, те пацијенткиња није имала потребу за хоспитализацијом.
Добро едукован болесник може и поред суочавања са хроничном болешћу имати добар квалитет живота. Циљ је препознавање симптома и тегоба, избегавање алергена, правовремено и исправно лечење да би се оболелима од алергијског ринитиса и бронхијалне астме омогућио што нормалнији живот.

\section{ЛИТЕРАТУРА}

1. Brozek JI, Bousquet J, Baena-Cagnani CE. Allergic Rhinitis and its Impact on Asthma (ARIA) guidelines: 2010 revision. J. Allergy Clin Immunol 2010; 126: 466-76.

2. Scadding GK. Allergic rhinitis: background, symptoms, diagnosis and treatment options. Nurs Times 2009; 105: 24-7.

3. Wallace DV, Dykewicz MS, Bemstein DI, et al. The diagnosis and management of rhinits: an updated practice parametar. J Allergy Clin Immunol 2008; 122.

4. Tran NP, Vickery J, Blaiss MS. Management of Rhinitis: Allergic and NonAllergic. Allergy Asthma Immunol Res. 2011; 3: 148-56.

5. Живковић Ђ. Болести органа за дисање; У: Интерна медицина, уредник Илић С. и сар. Медицински факултет у Нишу, 2009, 61-73.

6. Станковић И., Астма и хронична опструктивна болест плућа, сличности и разлике; У: Савремена сазнања о хроничној опструктивној болести плућа, уредник Станковић И., Медицински факултет Универзитета у Нишу, СВЕН Ниш, 2012, 87-100.

7. Bateman ED, Hurd SS, Barnes PJ, Bousquet J, Drazen JM, FitzGerald JM, et al. Global strategy for asthma management and prevention: GINA executive summary. Eur Respir J. 2008; 31: 143-78.

8. Global Iniciative for Asthma (GINA). Global Strategy for Asthma Management and Prevention. Online appendix. Updated 2015. Available from: www.ginasthma.org

9. Chen H, Gould MK, Blanc PD et al. Asthma control, severity and quality of life: quantifying the eff ect of uncontrolled disease. J Allergy Clin 2007; 120: 396-402. 10. Miedingerd, Neukomm E, Chhajed PN et al. The use of the Asthma Control Test in general practice. Curr Med Res Opin 2011; 27 (12): 2301-8.

11. Beam DS. Value of inhaled corticosteroid therapy in longterm asthma management. PT 2010; 35: 377-416.

Контакт: Др мед. Анита Накић, ул. Шантићева бр. 23А, 17500 Врање, тел: 063409 658, e-mail: anitanakic@yahoo.com 